\title{
Reduction of Polymerization Shrinkage in Adhesive Restaurations
}

\author{
Stefan Dačići, ${ }^{1,2}$ Milan Miljković ${ }^{3}$, Aleksandar Mitić1,2, Marija Nikolić1,2, \\ Marko Igić ${ }^{1,4}$, Milica Jovanović ${ }^{5}$ \\ ${ }^{1}$ University of Niš, Faculty of Medicine, Niš, Serbia \\ ${ }^{2}$ Department for Restorative Dentistry and Endodontics, Clinic of Dentistry, Niš, Serbia \\ ${ }^{3}$ University of Nis, Faculty of Medicine, Research Centre for Biomedicine, Niš Serbia \\ ${ }^{4}$ Department of Dental Prothetics, Clinic of Dentistry, NiŠ, Serbia \\ ${ }^{5}$ University of Kragujevac, Faculty of Medical Sciences, Department of Dentistry, Kragujevac, Serbia
}

\section{SUMMARY}

Composite materials used for the restoration of lost dental tissues fulfill almost all functional and aesthetic requirements. However, polymerization shrinkage still remains the main problem of light-curing composite resins. The consequences of this phenomenon are microfractures and microleakage in the marginal areas of the composite restoration.

The aim of this paper is to present the most important methods for reducing polymerization shrinkage of adhesive restorations, based on the contemporary literature available. These methods include changes in the chemical composition of the composite, correct application technique of the adhesive-composite system and selection of the appropriate light curing protocol.

In the last few years, composite materials have experienced significant changes in the chemical composition in order to compensate for their major shortcomings. By introducing pre-polymerized filler particles, alternative matrices based on silorane and ormocer, and new germanium-based photoinitiators, the degree of polymerization shrinkage has been significantly reduced.

Optimal adhesive bond between the filling and the tooth can compensate volumetric shrinkage of material which occurs during polymerization. Numerous studies have shown that total-etch adhesive systems, in comparison with self-etch, form a better adhesive bond to hard dental tissues. Polymerization shrinkage can also be reduced and marginal adaptation improved by applying a stress-absorbing layer and preheated composite.

With the use of modified light-curing protocols, such as soft start with reduced initial light intensity, and pulse-delayed with relaxation period, the negative effects of polymerization shrinkage and stress development can be further reduced, and the risk of microfracture formation minimized.

Key words: polymerization shrinkage, microfracture, bulkfill composite, soft start, pulse delay

Corresponding author:

Milan Miljković

Email:milandent89@yahoo.com 


\section{INTRODUCTION}

Composite materials have been successfully used in restorative dentistry for more than six decades. Excellent aesthetics, biocompatibility, resistance to wear during mastication and simple clinical application, are the main properties that have contributed to the popularization of composite materials in relation to amalgam fillings. With always increasing aesthetic demands and the development of new adhesive techniques, composite resins have become the material of choice for tooth restoration. In spite of numerous positive properties of commercially available composites, polymerization shrinkage and consequential microfracture and microleakage, still continue to pose the most significant problems of modern composite materials (1).

Polymerization shrinkage of composite resin occurs during the polymerization process due to reduction of intermolecular distance between the monomer units. In most composite materials, reduction in volume caused by polymerization shrinkage varies from $2 \%$ to $4 \%$. Polymerization shrinkage also generates initial and residual stress, which can remain trapped within the material itself, or it can be transferred to the surrounding dental structures and the marginal juncture between the tooth and filling (2). In clinical conditions, when the composite is placed inside the cavity and bonded to the surrounding walls of hard dental tissues, deformation of material is limited, which is why the polymerization stress is transferred to the area of marginal juncture in the form of tensile forces. When the polymerization stress exceeds the strength of adhesive bond, the marginal juncture is lost. As a result, microfracture and microleakage appear between the dental filling and cavity walls (3). Clinical manifestations of microleakage include marginal discoloration, postoperative sensitivity, secondary caries and damage to the pulp. Dental tissues and restorative material should have similar modules of elasticity. Materials with higher modulus of elasticity have an increased resistance to occlusal forces, resulting in more frequent fractures in the enamel. On the other hand, when materials with lower modulus of elasticity are used for replacing lost dental tissues, fractures occur more often in the area of marginal juncture (4).

The degree of polymerization shrinkage is affected by many factors, primarily by the selection of composite resin and light source. The results of previous studies have shown that the composite resin type has greater impacton the quality of the final restoration thanthe light source type. Application technique of the chosen composite and light curing protocol are also very important and need to be taken into account for each case individually. Currently, there is no material on the dental market that fully meets all the requirements of modern dentistry. Some of the disadvantages of existing composite systems can be overcome or completely eliminated by using appropriate clinical protocols and correct application techniques (5).

The aim of this paper is to present, on the basis of contemporary literature, the most important methods for reducing polymerization shrinkage of adhesive restorations. They can be divided into methods that dental material manufacturers seek to influence the reduction of polymerization shrinkage, and methods that therapists implement in their everyday clinical work.

\section{CHANGES IN THE CHEMICAL COMPOSITION OF COMPOSITE MATE- RIALS}

The chemical composition of composite materials for dental fillings has changed significantly from the period when they were first introduced into dental practice. Changes were necessary not only to reduce polymerization shrinkage and stress, but also to improve their mechanical and aesthetic properties. These modifications primarily refer to the composition of inorganic fillers, but also to alternative organic matrices and new, highly reactive photo-initiating systems (6).

Numerous studies have shown that the degree of polymerization shrinkage depends on the shape, size and amount of inorganic fillers. Filler particles are responsible for redistribution of forces generated by the conversion of monomers into polymer chains. The size of filler particles added to commercial composites has a tendency to decrease over time. The development of nanotechnology enabled introduction of nanofillers into dental composites, which led to a significant improvement in their mechanical properties. By increasing the content of inorganic fillers in dental composites, the degree of polymerization shrinkage and stress has been reduced. However, if the content of filler becomes relatively high, the consistency of composite resin becomes denser due to the increase in viscosity, and it becomes unsuitable for clinical use (7).

Reduction of polymerization shrinkage was also achieved by introducing silorane and ormocer into the organic matrix of dental composites. The results of numerous studies, comparing silorane-based composites 
to conventional composites based on methacrylate, have shown reduction of polymerization shrinkage to $0.9 \%$ and postoperative hypersensitivity to $0.1 \%$. Due to specific properties of silorane, marginal adaptation is also improved and depth of polymerization increased to $2.5 \mathrm{~mm}$. The mechanism for reducing polymerization shrinkage is based on the opening and dissemination of the silane-oxirane ring during polymerization process (Figure 1), thereby compensating for the reduction in volume generated by cross-linking of the monomer molecules (8).
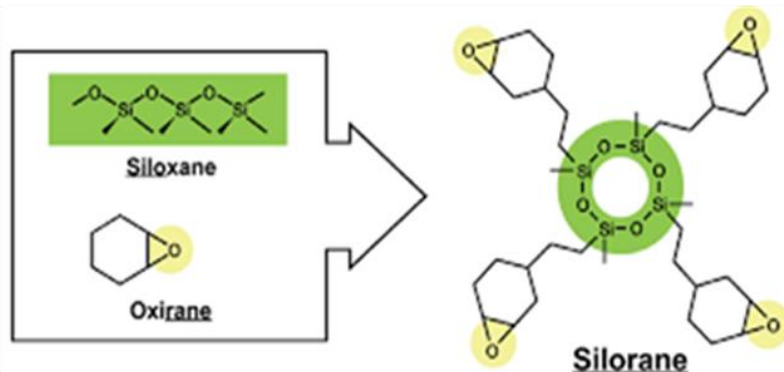

Silorane

\section{Figure 1. Chemical structure of silorane}

Because of the specific structure of ormocer molecules, the number of free radicals and release of harmful monomers is significantly reduced. Thus, the biocompatibility of ormocer-based composites is higher in relation to conventional composites. Due to the fact that the values of thermal expansion coefficient of ormocer are similar to the values of hard dental tissues, polymerization shrinkage is reduced to $1.9 \%$. Also, compared to conventional composites, ormocer-based composites have increased abrasion resistance and marginal integrity (9).

The lack of conventional composites to provide correct light curing of layers thickerthan $2 \mathrm{~mm}$ is exceeded by introducing bulkfill composites into dental practice. Bulkfill composites can be placed in thicker layers $(4-5 \mathrm{~mm})$ because they have a higher degree of translucency and highly reactive photoinitiators in order to provide optimum light transmission to the deepest layers of composite (10). Reduction of polymerization shrinkage was achieved by including new expanding monomers (AUDMA) into the organic matrix, which are less viscous and more flexible than Bis-GMA. Bulkfill composites also contain stress modulators that affect the speed and development of the polymer network. By incorporating prepolymerized filler particles, polymerization shrinkage is reduced to $1 \%$. The filler particles processed in this way are not subjected to shrinkage during re-polymerization, and increase the mass fraction of the filler by $15 \%$. By introducing new germaniumbased photoinitiators, such as Ivocerin, the bulkfill composite's optical properties have been significantly improved in terms of shortened curing time and increased depth of polymerization. Ivocerin has a higher light-curing activity than camorphinone, due to higher light absorption in the wavelength range 400-450 nm and it can be used without amine as a co-initiator (11).

\section{SELECTION OF COMPOSITE APPLICATION TECHNIQUE}

The longevity of composite restorations depends to a large extent on the formation of a high-quality adhesive bond between the filling and hard dental tissues. Sufficient adhesive bond strength can compensate for the polymerization shrinkage which occurs during light curing of the composite. During time, dental adhesive systems have evolved in the direction of simplifying the clinical procedure and reducing the number of adhesive components. Today, we have "all-in-one" dental adhesives, which contain primer and adhesive in the same bottle. Popular dental adhesive systems achieve micromechanical and chemical bonding with hard dental tissues. Depending on whether the smear layer is completely or partially removed, they are divided into two groups: total-etch and self-etch. Total-etch adhesive systems include the use of phosphoric acid for etching, which is then rinsed off with water. Optimal etching time is recommended by the manufacturer and should not be exceeded since excessive etching can cause irreversible damage to the nearby pulp tissue. Self-etch adhesive systems include conditioning of the cavity walls with non-rinsing primers. Based on the chemical composition, primers are weak acids (12). The results of previous studies have shown that cavity treatment with phosphoric acid significantly increases the micro retential surface, involved in the bonding of composite to enamel and dentin, and enables the formation of a thick hybrid layer $(8-10 \mathrm{~mm})$. The use of self-etch adhesive system enables the formation of a thinner hybrid layer $(5-8 \mu \mathrm{m})$ due to insufficient etching by slightly acidic primers that remain permanently incorporated in the tooth surface as they do not rinse with water. The advantages of total-etch adhesive systems include optimal bonding to enamel and dentin, and sufficient thickness of the hybrid layer which increases the adhesive bond strength. Disadvantages include sensitivity of the procedure, risk of excessive etching or insuf- 
ficient rinsing, and the possibility of leaving overdried or wet dentin $(13,14)$.

Restoration of deep cavities in the lateral segments of the tooth arch is a very common therapeutic procedure in everyday dental practice. Often, it can be time-consuming and technically rather demanding. It is known that the degree of polymerization shrinkage and stress distribution is influenced by the cavity size and design. Class I and II fillings have the highest C-factor values, making them most susceptible to the influence and effects of polymerization stress. Limiting factor in the use of conventional composites is that proper light curing of the material can be achieved only in layers up to $2 \mathrm{~mm}$ thick. Therefore, the restoration of deep cavities requires a specific incremental technique of composite application, in order to reduce the degree of polymerization shrinkage. In addition, applying composite layers of different color results in better matching of material's optical characteristics with the remaining dental tissues. The use of incremental technique requires an absolute dry working field which can be obtained by cofferdam isolation (15).

In a study conducted by Petrović et al., a modified incremental technique with pin application was presented in order to reduce the polymerization stress. The basic idea of applying a pin in the geometric center of the cavity is to eliminate the point of stress concentration and modify its distribution during the polymerization process. Eliminating the central point of stress improves the marginal adaptation of composite filling. Pin cavity formed in the composite is then filled with a second layer of liquid composite. By using this method, the surface of unbound composite is increased, while at the same time the volume of the first layer of composite is reduced. However, incremental technique has numerous disadvantages, such as: possibility of incorporating cavities or contamination between the layers of composite, failure to form a bond between the layers, extended working time required for modeling and curing each individual layer in the patients mouth, compromising the quality of final restoration $(16,17)$.

Changes in the chemical composition of the composite enabled its application using bulk or fast-track technique. Bulk technique is gaining more and more popularity among clinicians, especially in the restoration of lateral teeth. It enables application and light curing of bulkfill composites in one layer, $4-5 \mathrm{~mm}$ thick. In this way, the restoration procedure and working time in the patient's mouth are significantly reduced. The only lack of bulk technique are weaker aesthetic properties of final restoration compared to incremental technique with different colors (18).

Another recommended method for reducing negative effects of polymerization stress in high C-factor cavities is the application of stress-absorbing layer. By placing a liner with a low modulus of elasticity between the tooth and the composite, the development of polymerization stress is decreased. Due to the low content of filler, liquid composite has a smaller modulus of elasticity by $20-30 \%$ and greater deformation capacity, compared to conventional composites. This contributes to reduction of polymerization shrinkage in the overlaying composite material (19).

Lately, the influence of temperature on polymerization shrinkage and stress development in the composite materials has been increasingly studied. The increase in temperature accelerates polymerization reaction and improves the cross-linking of polymer chains. Higher degree of conversion leads to better mechanical properties of the material. Heating of the composite results in a decreased viscosity and increased flow of the material, thereby improving the marginal adaptation, especially in the corners of the cavity (20). However, in clinical conditions it is difficult to maintain the elevated temperature of composite, due to the timeconsuming procedure of placing, modeling and light curing of the composite. In a study conducted by Daronch et al., it was found that the temperature of composite material heated at $60^{\circ} \mathrm{C}$ decreased by $50 \%$ after 2 minutes, and $90 \%$ after 5 minutes (21).

Heating the composite at high temperature is not favorable, because the increase of the pulp temperature by more than $6.5^{\circ} \mathrm{C}$ leads to irreversible damage, pulp necrosis, and pain. Normal increase of the pulp temperature by $4.2^{\circ} \mathrm{C}$ occurs during light activation of the composite resin, which is an effect produced by a combination of an exothermic polymerization reaction and light emitted by the curing source. In a study conducted by Lohbauer et al., the increase of pulp temperature was measured at a distance of $2 \mathrm{~mm}$ from the heated composite. The results suggested that the composite heated at $68^{\circ} \mathrm{C}$ increased the pulp temperature by only $1.2^{\circ} \mathrm{C}(22)$.

Negative effects of polymerization shrinkage and stress development can be compensated by the improved marginal adaptation and shortened light curing time of the heated composite. In a study conducted by Calherios et al., it was found that light activation of composite filler heated to $40-60^{\circ} \mathrm{C}$ for 5 seconds resulted in $47-55 \%$ stress reduction, compared 
to light curing of composite at room temperature for 20 seconds (23).

\section{SELECTION OF THE LIGHT CURING PROTOCOL}

The main requirement for complete and correct polymerization of the composite material is sufficient amount of light energy of particular wavelength. Inadequate light polymerization results inreduced conversion of the organic component of composite resin. This way, the content of residual monomer in the material is increased. This residual monomer contributes to poor mechanical properties of the composite filling. It can also diffuse into the pulp chamber directly through dentin tubes and cause genotoxic and cytotoxic effects on the pulp cells (24). Therefore,it is very important to know the minimum light intensity required for achieving a satisfying degree of conversion and ensuring optimal mechanical properties of the composite filling. Recent studies have concluded that $116 \mathrm{~mW} / \mathrm{cm}^{2}$ of total light energy emitted from the source is sufficient enough for the successful development of polymerization process. This differs significantly from the results of previous studies, where it was determined that 400 $\mathrm{mW} / \mathrm{cm}^{2}$ is the minimum light intensity required for optimal development of polymerization process (25).

By emitting a lower light intensity to activate the polymerization process, a smaller amount of free radicals is formed, compared to the applied higher light intensity. Reduced level of free radicals causes initially more linear polymerization and delayed interaction between adjacent polymer chains, i.e. cross-linking. This way, the reach of gel point is delayed and the period of mobility of the reactive molecules is prolonged prior to reaching the vitrification. The viscous flow, which happens only in the pre-gel phase, is one of the basic relaxation mechanisms for reduction of shrinkage and stress which occur during the polymerization process (26).

When using standard light curing protocol with continuous emission of light energy over time, reaching the gel point occurs at the very beginning of the polymerization process. Two modified light curing protocols, soft start and pulse-delayed, were introduced into dental practiceas an alternative to the standard protocol. The basic mechanism for reducing polymerization shrinkage and stress is based on delaying the reach of gel point and prolonging the period of viscous flow (27).
Soft start is a two-step light curing protocol. Initially, lower light intensity is applied in order to extend the gel phase. In the second phase, light intensity increases exponentially to its maximum value during a 10 -second period and remains constant for the duration of exposure. The results of numerous studies have validated that decreased initial intensity of light energy slows down the speed of polymerization process and the development of contraction stress. This way the marginal integrity of the composite filling is significantly improved. The modifications of curing protocol do not compromise the mechanical properties of the material. On the contrary, it has been confirmed that the postpolymerization properties of the composite (microhardness, flexion modulus, tensile strength, conversion rate) have been significantly improved after using soft start polymerization protocol $(28,29)$.

Pulse-delayed light curing protocol is based on the results of numerous studies which showed that the majority of contraction tension of the composite develops in the first seconds of light polymerization. Tension also appears at low initial light intensity, so it is necessary to ensure a period of relaxation, which can be achieved by interrupting the light polymerization. The pulse-delayed protocol provides a relaxation interval (dark interval) between the first short-term pulse and the final, continuous light polymerization. This relaxation interval enables stress reduction by increasing the flow and deformation ability of polymer chains. Another explanation for stress reduction is the formation of more linear structure with less cross-linking between the polymer chains. The question of dark interval duration still remains an actual topic of many researches. In deep cavities, this curing protocol is mainly used for the last composite increment (30).

\section{CONCLUSION}

By changing the chemical composition and creating the conditions for proper polymerization at a greater depth, the degree of polymerization contraction of the composite materials is reduced to $1 \%$. The contraction stress that occurs during the light polymerization of the composite can be compensated by optimal adhesive bond between the filling and hard dental tissues. Total-etch adhesive systems achieve a stronger bond than self-etch systems, thanks to the conditioning of cavity walls with phosphoric acid, which significantly increases the microretential surface. By introducing a stress-absorbing layer in high C-factor 
cavities and heating the composite, the degree of polymerization shrinkage can be further reduced and the marginal adaptation significantly improved. The use of modified light curing protocols, soft start and pulsedelayed can additionally reduce the negative effects of polymerization stress development, without compromising the degree of conversion and the mechanical properties of composite materials.

Recommendations for clinical practice:

-restoration of cavities in the front with composites based on silorane and ormocer,

-restoration of cavities in the lateral segments of the tooth arch with bulkfill composites,

-underlying deep cavities with liners and liquid composites that take the role of a stress-absorbing layer, -etching of the cavity walls with phosphoric acid in order to increase the microretetial surface, -composite heating for improving marginal adaptation,

-use of soft start light curing protocol with low initial light intensity,

-use of pulse-delayed light curing protocol with a relaxation interval of 5-10s.

\section{Acknowledgments}

This study was supported by the Ministry of Education, Science and Technological Development of the Republic of Serbia (project number 41018). 


\section{References}

1. Jackson RD. Class II composite resin restorations: faster, easier, predictable. Br Dent J 2016; 221 (10): 623-31.

\section{https://doi.org/10.1038/si.bdj.2016.856}

2. Kaisarly D, Gezawi ME. Polymerization shrinkage assessment of dental resin composites: a literature review.Odontol 2016; 104 (3): 257-70.

https://doi.org/10.1007/s10266-016-0264-3

3. Al Sunbul H, Silikas N, Watts DC. Polymerization shrinkage kinetics and shrinkage-stress in dental resin-composites. Dent Mater 2016; 32 (8): 998-1006. https://doi.org/10.1016/i.dental.2016.05.006

4. Benetti AR, Peutzfeldt A, Lussi A, Flury S. Resin composites: Modulus of elasticity and marginal quality.J Dent 2014; 42 (9): 1185-92.

https://doi.org/10.1016/i.jdent.2014.07.004

5. Dačić S, Karuntanović T, Miljković N, Dačić M, Dačić-Simonović D, Mitić A. Uticaj vrste kompozitne smole i svetlosnog izvora na mikropropuštanje kompozitnih restauracija. Acta Fac Med Naiss 2018; 35(4): 337-44.

https://doi.org/10.2478/afmnai-2018-0036

6. Mahmoud SH, El-Embaby AE, AbdAllah AM. Clinical performance of ormocer, nanofilled, and nanoceramic resin composites in Class I and Class II restorations: a three-year evaluation.Open Dent 2014; 39 (1): 32-42.

https://doi.org/10.2341/12-313-C

7. Shibasaki S, Takamizawa $\mathrm{T}$, Nojiri $\mathrm{K}$, Imai $\mathrm{A}$ Tsujimoto A, Endo H. Polymerization Behavior and Mechanical Properties of High-Viscosity Bulk Fill and Low ShrinkageResin Composites. Oper Dent 2017; 42 (6): E177-87.

https://doi.org/10.2341/16-385-L

8. Mitthra S, Rajkumar K, Mahalaxmi S. Evaluation of polymerization shrinkage, polymerization shrinkage stress, wear resistance, and compressive strength of a silorane-based composite: A finite element analysis study. Indian J Dent Res 2017; 28(4): 375-9.

https://doi.org/10.4103/ijdr.IJDR 34815

9. Tauböck T, Jäger F, Attin T. Polymerization shrinkage and shrinkage force kinetics of high- and low-viscosity dimethacrylate- and ormocer-based bulk-fill resin composites. Odontology 2019; 107(1): 103-10.

https://doi.org/10.1007/s10266-018-0369-y

10. André F.R. Efficiency of polymerization of bulkfill composite resins: a systematic review. Braz Oral Res 2017;31(1): 57-9.

https://doi.org/10.1590/1807-3107bor-2017.vol31.0059

11. Bucuta S, Ilie N. Light transmittance and micromechanical properties of bulk fill vs. conventional resin based composites. Clin Oral Investig 2014; 18: 1991-2000.

https://doi.org/10.1007/s00784-013-1177-y

12. Dačić $\mathrm{S}$, Mitić $\mathrm{A}$, Nikolić $\mathrm{M}$, Dačić-Simonović $\mathrm{D}$, Veselinović A, Cenić M. Marginal adaptation of composite resins under two adhesive techniques. Microsc Res Tech 2016; 79(11): 1031-7.

https://doi.org/10.1002/jemt.22738

13. Dačić S, Dačić-Simonović D, Živković S, Radičević G,Mitić A,Veselinović A. SEM analiza kvaliteta ivičnog pripoja kompozitnih ispuna za gleđ posle primene totalno nagrizajućeg i samonagrizajućeg adhezivnog sistema. Srp Arh Celok Lek 2009; 137(910): $475-81$.

https://doi.org/10.2298/SARH0910475D

14. Dačić S, Mitić A, Popović J, Simonović-Dačić D, Igić M. Ultrastructure of adhesive bond of composite to dentin. Acta Fac Med Naiss 2014; 31(1): 67-73.

https://doi.org/10.2478/afmnai-2014-0007

15. Chandrasekhar V, Rudrapati L, Badami V, Tummala M. Incremental techniques in direct composite restoration. J Conserv Dent 2017; 20(6): 386-91.

https://doi.org/10.4103/JCD.JCD 15716

16. Petrovic Lj, Ramic B, Premovic M, Stojanac I, Drobac M. Improved marginal adaptation of composite restorations by using different placement and light polymerization techniques. Am J Dent 2018; 31(1): 7-12. 
17. Petrovic Lj, Drobac M, Stojanac I, Atanackovic T. A method of improving marginal adaptation by elimination of singular stress point in composite restorations during resin photopolymerization. Dent Mater 2010; 26: 449-55.

https://doi.org/10.1016/j.dental.2009.11.160

18. Jang JH, Park SH, Hwang IN. Polymerization shrinkage and depth of cure of bulk-fill resin composites and highly filled flowable resin.Oper Dent 2015;40(2):172-80.

https://doi.org/10.2341/13-307-L

19. Correia AMO, Tribst JPM, Matos FS, Platt JA, Caneppele TMF, Borges ALS. Polymerization shrinkage stresses in different restorative techniques for non-carious cervical lesions. J Dent 2018; 76: 6874.

https://doi.org/10.1016/j.jdent.2018.06.010

20. Ahn KH, Lim S, Kum KY, Chang SW. Effect of preheating on the viscoelastic properties of dental composite under different deformation conditions. Dent Mater J 2015; 34 (5): 702-6.

https://doi.org/10.4012/dmj.2015-042

21. Daronch M, Rueggeberg FA, Moss L, de Goes MF. Clinically relevant issues related to preheating composites. J Esthet Restor Dent 2006; 18: 340-50.

https://doi.org/10.1111/j.1708-8240.2006.00046.x

22. Andreatta LM, Furuse AY, Prakki A, Bombonatti JF, Mondelli RF.Pulp Chamber Heating: An In Vitro Study Evaluating Different Light Sources and Resin Composite Layers. Braz Dent J 2016; 27 (6): 675-80.

https://doi.org/10.1590/0103-6440201600328

23. Calheiros FC, Daronch M, Rueggeberg FA, Braga RR. Effect of temperature on composite polzmerization sress and degree of conversion. Dent Mater 2014; 30: 613-8.

https://doi.org/10.1016/j.dental.2014.02.024

24. Dačić S, Djelić N, Radaković M, Lakić N, Veselinović A , Ristanić M. Uticaj fotopolimerizacije na genotoksičnost kompozitnih adheziva $\mathrm{u}$ komet testu. Genetika 2016; 48(2): 617-27.

https://doi.org/10.2298/GENSR1602617D

25. Emami N, Soderholm K. Berglund L. Effect of light power density variations on bulk curing properties of dental composites. J Dent 2003;31:18996.

https://doi.org/10.1016/S0300-5712(03)00015-0

26. Papadogiannis D, Tolidis K, Gerasimou P, Lakes R, Papadogiannis Y. Viscoelastic properties, creep behavior and degree of conversion of bulk fill composite resins. Dent Mater 2015; 31(12): 1533-41. https://doi.org/10.1016/j.dental.2015.09.022

27. Zorzin J, Maier E, Harre S, Fey T, Belli R, Lohbauer U, Petschelt A, Taschner M. Bulk-fill resin composites: polymerization properties and extended light curing. Dent Mater 2015; 31 (3): 293-301. https://doi.org/10.1016/j.dental.2014.12.010

28. Gamarra V, Borges G, Júnior L, Spohr A. Marginal adaptation and microleakage of a bulk-fill composite resin photopolymerized with different techniques. Odont 2018; 106(1): 56-63.

https://doi.org/10.1007/s10266-017-0294-5

29. Dačić S, Dačić-Simonović D, Živković S, Radičević G, Mitić A, Tošić G. Analiza ivičnog pripoja kompozitnih smola za gleđ skening-elektronskom mikroskopijom nakon primene standardne i postepene tehnike fotopolimerizacije. Srp Arh Celok Lek 2014;142(7-8): 404-12.

https://doi.org/10.2298/SARH1408404D

30. Tauböck TT, Feilzer AJ, Buchalla W, Kleverlaan CJ, Krejci I, Attin T. Effect of modulated photoactivation on polymerization shrinkage behavior of dental restorative resin composites. Eur J Oral Sci 2014; 122 (4): 293-302.

https://doi.org/10.1111/eos.12139 


\title{
Redukcija polimerizacione kontrakcije adhezivnih restauracija
}

\author{
Stefan Dačić1,2, Milan Miljković3, Aleksandar Mitić 1,2, Marija Nikolić1,2, \\ Marko Igić1,4, Milica Jovanović ${ }^{5}$ \\ ${ }^{1}$ Univerzitet u Nišu, Medicinski fakultet, Niš, Srbija \\ ${ }^{2}$ Odeljenje za restorationu stomatologiju i endodonciju, Klinika za stomatologiju, Niš, Srbija \\ ${ }^{3}$ Univerzitet u Nišu, Medicinski fakultet, Istraživački centar za biomedicinu, Niš, Srbija \\ ${ }^{4}$ Odeljenje za stomatološku protetiku, Klinika za stomatologiju, Niš, Srbija \\ ${ }^{5}$ Univerzitet u Kragujevcu, Fakultet medicinskih nauka, Departman za stomatologiju, Kragujevac, Srbija
}

\section{SAŽETAK}

Kompozitni materijali koji se danas koriste za restauraciju izgubljenih zubnih tkiva, ispunjavaju skoro sve funkcionalne i estetske zahteve. Međutim, glavni problem svetlosnopolimerizujućih kompozita i dalje ostaje pojava kontrakcije prilikom polimerizacije. Posledice ovog fenomena su nastanak mikropukotine i mikrocurenja u predelu marginalnog spoja.

Cilj ovog rada je da na osnovu savremene dostupne literature, predstavi najznačajnije metode za smanjenje kontrakcije adhezivnih restauracija. To su: promena hemijskog sastava kompozita, pravilna tehnika aplikovanja adhezivno-kompozitnog sistema i izbor odgovarajućeg režima svetlosne polimerizacije.

Kompozitni materijali su zadnjih godina doživeli najviše promena u pogledu hemijskog sastava, sa ciljem kompenzovanja njihovih glavnih nedostataka. Uvođenjem prepolimerizovanih čestica punioca, alternativnih matriksa na bazi silorana i ormocera, i novih fotoinicijatora na bazi germanijuma, u značajnoj meri je redukovan stepen polimerizacione kontrakcije.

Kvalitetna adhezivna veza između ispuna i zuba može kompenzovati kontrakciju materijala koja nastaje prilikom polimerizacije. Brojna istraživanja su pokazala da totalno nagrizajući adhezivni sistemi, u poređenju sa samonagrizajućim, omogućavaju formiranje bolje adhezivne veze za tvrda zubna tkiva. Uvođenjem stresapsorbujućeg sloja i zagrevanjem kompozita, može se dodatno smanjiti polimerizaciona kontrakcija i poboljšati marginalna adaptacija.

Primenom modifikovanih režima svetlosne polimerizacije (soft start i pulse-delayed), sa smanjenim početnim intenzitetom svetlosne energije i periodom relaksacije, takođe se mogu umanjiti negativni efekti razvitka polimerizacione kontrakcije i stresa, a rizik od nastanka mikropukotine svesti na minimum.

Ključne reči: polimerizaciona kontrakcija, mikropukotina, bulkfill kompozit, soft start, pulse delay 